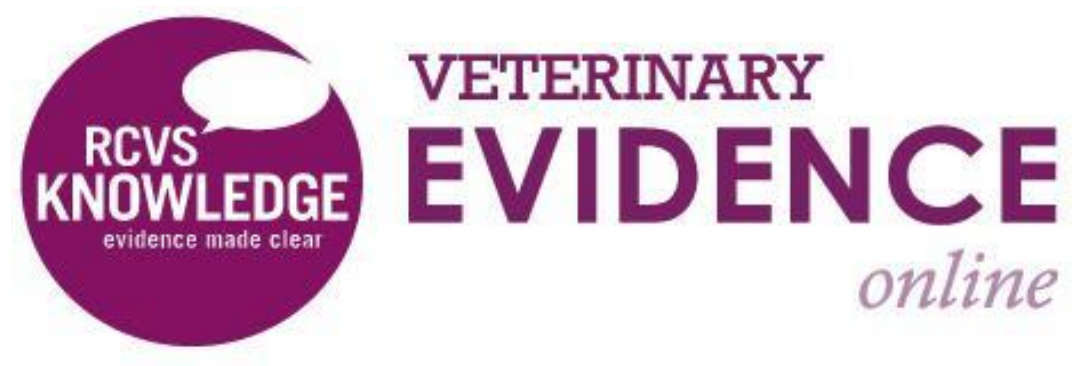

\title{
The Use of Antibiotics in Broodmares With Post- service Endometritis
}

A Knowledge Summary by

Elizabeth Barter BVSc, MRCVS ${ }^{1^{*}}$

Annalisa Barrelet BVetMed, MSc, CertESM, MRCVS ${ }^{1}$

\footnotetext{
${ }^{1}$ Rossdales and Partners, Beaufort Cottage Laboratories, High Street Newmarket, Suffolk CB8 8JS

*Corresponding Author (ebarter@bigpond.net.au)
}

ISSN: 2396-9776

Published: 19 Jan 2018

in: Vol 3, Issue 1

DOI: http://dx.doi.org/10.18849/ve.v3i1.132

Reviewed by: Polly Compston (BSc (Hons), BVM\&S, MSc) and Adam Swallow (BVSc, AFHEA, MRCVS) 
KNOWLEDGE SUMMARY

\section{Clinical bottom line}

There is currently a lack of evidence to suggest that antibiotics delivered into the uterus post-service improves pregnancy rates. The evidence does support that post-service treatment with or without antibiotics improves pregnancy rates in mares with endometritis compared to no treatment (pregnancy rates between $40-90 \%$ compared to $0-56 \%$ respectively). The studies further identify the need to recognise mares at risk of post-service endometritis to target appropriate therapy.

\section{Question}

In broodmares with post-service endometritis after natural cover, is antibiotic intervention superior to other routine therapies without antibiotic intervention in increasing pregnancy rates?

\section{Clinical Scenario}

It is well recognised that endometritis decreases pregnancy rates (Le Blanc and Cause 2009). However, there is no clear definition of post-service endometritis (Le Blanc and Cause 2009). When mares are presented post-service, and suspected to have endometritis a decision is required by the clinician to use or not use antibiotics in combination with other routine therapies such as uterine flushing and ecbolic agents. It is often unknown when the clinician is making an assessment if the endometritis is infectious or sterile in origin and mares are currently recommended to be treated with antibiotics regardless of cause (Morel 2003; Blanchard et.al., 2000). The use of antibiotics should be evidence-based to minimise the risk of microbial resistance and opportunist fungal infections (Assad et.al. 2015).

\section{The Evidence}

Seven publications were identified in the literature searches. These comprised 2 descriptive studies, 1 observational study, 2 randomised non-blinded controlled trials and 2 non-randomised non-blinded controlled trials. Included publications were of level 3 (randomised control trials) or level 4 (lower quality controlled trial) (OCEBM Levels of Evidence Working Group). The outcomes studied varied between the studies including pregnancy rates at 15 days (Pycock and Newcombe 1996; Gores-Lindholm et.al. 2013; Sharma et.al. 2011), 45 days (El-Roos 2004), 60 days (Noseir 2002; Taha 2007), or unknown (Pascoe 1990). Further, there was no standard population treated, antibiotic prescribed or method of administration between the studies.

In the three studies with no case selection any treatment was seen to benefit pregnancy rates over no treatment at all (Pycock and Newcombe 1996; Pascoe 1990; El-Roos 2004). This is similar to mares with a previous history of endometritis with a significantly higher pregnancy rate in mares treated with antibiotics and ecbolic agents compared to no treatment at all (Noseir 2002; Taha 2007). In the two studies which compared mares with and without signs of endometritis and treatment with antibiotics, higher pregnancy rates were achieved in mares that were not treated and had no signs of endometritis (Sharma et al., 2011; Gores-Lindholm et.al., 2013). The findings support the need for case selection in treating mares with postservice induced endometritis. 


\begin{tabular}{|c|c|}
\hline \multicolumn{2}{|l|}{ Pycock (1996) } \\
\hline Population: & $\begin{array}{l}574 \text { Thoroughbreds, } 647 \text { hunters (crossbreds) and } 46 \text { pony types } \\
\text { with ages ranging from } 3-22 \text { years and mixed reproductive status } \\
\text { (maiden, barren, post-parturient) }\end{array}$ \\
\hline Sample size: & $\mathrm{n}=1267$ \\
\hline Intervention details: & $\begin{array}{l}\text { Mares were assigned in rotation to one of four treatment groups. } \\
\text { Group 1: no treatment ( } n=322) \\
\text { Group 2: intrauterine antibiotic treatment within } 72 \text { hours of mating } \\
\text { ( } 1200 \mathrm{mg} \text { procaine penicillin combined with } 1500 \mathrm{mg} \\
\text { dihydrostreptomycin and } 900 \mathrm{mgs} \text { framycetin made to a volume of } \\
12 \mathrm{mls} \text { or neomycin }(1 \mathrm{~g}) \text { polymyxin } \mathrm{B}(40,000 \mathrm{iu}) \text { and furaltadone } \\
(600 \mathrm{mg}) \text { with crystalline benzylpenicillin }(3 \mathrm{~g}) \text {. ( } \mathrm{n}=317) \\
\text { Group 3: oxytocin }(25 \mathrm{iu}) \text { administered by IV injection within } 72 \\
\text { hours of mating ( } \mathrm{n}=316) \\
\text { Group 4: oxytocin }(25 \mathrm{iu}) \text { administered IV followed } 30 \text { mins later by } \\
\text { intrauterine antibiotics as described for group } 2 \text { within } 72 \text { hours } \\
\text { after mating }(\mathrm{n}=314)\end{array}$ \\
\hline Study design: & Prospective non-blinded, non-randomised controlled- trial \\
\hline Outcome studied: & $\begin{array}{l}\text { Ultrasound pregnancy detection on day } 13,14 \text {, or } 15 \text { post ovulation } \\
\text { and repeat examination between } 27-30 \text { days after ovulation. Early } \\
\text { embryonic death rate determined by the presence of a vesicle at } \\
\text { first scan and absence at second scan }\end{array}$ \\
\hline $\begin{array}{l}\text { Main findings: } \\
\text { (relevant to PICO question): }\end{array}$ & $\begin{array}{l}\text { - Any treatment (oxytocin alone or in combination with intrauterine } \\
\text { antibiotics) significantly increased pregnancy rates over untreated } \\
\text { control mare (control pregnancy rate } 56 \% \text { ) } \\
\text { - No difference in pregnancy rates between group } 2 \text { (intrauterine } \\
\text { antibiotics) (64\%) and group } 3 \text { (oxytocin) mares (63\%) } \\
\text { - Mares in group } 4 \text { (intrauterine antibiotics and oxytocin) had higher } \\
\text { pregnancy rates than mares in group } 2 \text { and group } 3 \text { (group } 4 \\
\text { pregnancy rate } 72 \% \text { ) } \\
\text { - No difference in early embryonic loss between treatment groups }\end{array}$ \\
\hline Limitations: & $\begin{array}{l}\text { - Mares were not subject to any diagnostic procedure to confirm } \\
\text { the presence or absence of infection prior to antibiotic treatment } \\
\text { - There was no data pertaining to presence of clinical or subclinical } \\
\text { signs of endometritis such as intraluminal fluid within the groups } \\
\text { prior to treatment } \\
\text { - Unknown spread of ages and reproductive status (barren, maiden, } \\
\text { post-parturient) within groups } \\
\text { - Unknown if mares were selected at foal heat or recruited to the } \\
\text { study after multiple mating attempts during the season }\end{array}$ \\
\hline
\end{tabular}




\begin{tabular}{|c|c|}
\hline \multicolumn{2}{|l|}{ Pascoe (1990) } \\
\hline Population: & $\begin{array}{l}\text { Unknown population of foaling mares bred on foal heat, short cycled } \\
\text { and bred at } 18 \text { days or bred after } 30 \text { days }\end{array}$ \\
\hline Sample size: & $\mathrm{n}=1090$ \\
\hline Intervention details: & $\begin{array}{l}\text { Mares were treated post ovulation with plasma and intrauterine } \\
\text { antibiotic ( } n=420 \text { composed of foal heat } n=240 \text {; short cycled } n=100 \text {; } \\
\text { and bred after } 30 \text { days } n=80 \text { ), intrauterine antibiotic alone ( } n=450 \\
\text { composed of foal heat } n=240 \text {; short cycled } n=100 \text {; and bred after } 30 \\
\text { days } n=110 \text { ) or control no treatment ( } n=220 \text { composed of foal heat } \\
n=120 \text {; short cycled } n=50 \text {; and bred after } 30 \text { days } n=50 \text { ). (Antibiotic } \\
\text { used was } 6 \text { million IU procaine penicillin and } 4 \text { gm neomycin } \\
\text { sulphate) }\end{array}$ \\
\hline Study design: & Observational study \\
\hline Outcome studied: & Conception rate (unknown determination) \\
\hline $\begin{array}{l}\text { Main findings: } \\
\text { (relevant to PICO question): }\end{array}$ & $\begin{array}{l}\text { - In mares that were short cycled plasma and antibiotic infusion } \\
\text { increased conception rates by } 30 \% \text { compared to mares that had } \\
\text { no treatment. } \\
\text { - Mares bred on foal heat had higher conception rates when treated } \\
\text { with plasma and antibiotic infusion ( } 74 \%) \text { or antibiotic infusion } \\
\text { (64\%) alone, than no treatment }(52 \%)\end{array}$ \\
\hline Limitations: & $\begin{array}{l}\text { - The population of mares within groups regarding age, } \\
\text { reproductive status, previous endometritis and breed is unknown. } \\
\text { - No statistical analysis was performed to determine the significance } \\
\text { of the findings } \\
\text { - No data regarding signs of clinical or subclinical endometritis } \\
\text { within the groups }\end{array}$ \\
\hline
\end{tabular}

\begin{tabular}{|c|c|}
\hline \multicolumn{2}{|l|}{ Taya (2007) } \\
\hline Population: & $\begin{array}{l}\text { Arabian maiden mares ranging from } 4 \text { to } 8 \text { years with a diagnosis of } \\
\text { persistent mating induced endometritis. Mares were determined to } \\
\text { have persistent mating induced endometritis if they met one of } 3 \\
\text { criteria: } \\
\text { - A history of repeat breeding (more than } 3 \text { natural services and no } \\
\text { signs of pregnancy) } \\
\text { - Intrauterine fluid present one/two days after breeding or } \\
\text { - Endometrial cytology showing }>5 \% \text { PMN cells }\end{array}$ \\
\hline Sample size: & $n=42$ \\
\hline Intervention details: & $\begin{array}{l}\text { Mares } 6 \text { hours after breeding received a uterine lavage with } \\
\text { antibiotics ( } n=36) .8 \text { hours after breeding mares were divided into } 3 \\
\text { groups ( } n=12 \text { in each group) and received either prostaglandin } \\
\text { ( } 250 \text { ug cloprostenol SC), or oxytocin ( } 20 \text { I.U IM), or no treatment. } \\
\text { Control mares ( } n=6) \text { received no treatment. Uterine lavage was } \\
\text { performed with } 500 \mathrm{mI} \mathrm{N-saline} \mathrm{containing} 4 \text { million IU of crystalline } \\
\text { penicillin and } 4 \text { g streptomycin sulphate }\end{array}$ \\
\hline
\end{tabular}




\begin{tabular}{|r|l|}
\hline Study design: & Prospective, randomised, non-blinded controlled trial \\
\hline Outcome studied: & Pregnancy rate after 2 months of treatment \\
\hline Main findings: & - There was a significantly higher pregnancy rate in mares that had a \\
(relevant to PICO question): & uterine lavage containing antibiotics and an injection of \\
& prostaglandin (83.3\%) compared to other treatment groups \\
& - There was no difference in pregnancy rates between mares \\
& receiving antibiotic lavage alone (50\%) or combined with oxytocin \\
& $(66.6 \%)$ \\
& - All treatments significantly increased pregnancy rates over control \\
& (untreated) mares (0\%) \\
\hline \multirow{5}{*}{ Limitations: } & - No comparison was made to treatment without antibiotics such as \\
& oxytocin alone \\
& - No description of how randomisation was performed and if mares \\
& were randomised based on criteria for selection into the study \\
& between treatment groups \\
& - Unusual antibiotic delivery through lavage system and unusual \\
& cytology performed from antibiotic flush \\
& - No cytology or culture performed prior to antibiotic lavage \\
& - No evidence of other complicating factors such as presence of \\
& fluid or uterine oedema \\
\hline
\end{tabular}

\begin{tabular}{|c|c|}
\hline \multicolumn{2}{|l|}{ Gores-Lindholm (2013) } \\
\hline Population: & $\begin{array}{l}\text { Mares aged } 4-24 \text { years majority thoroughbred ( } 3 \text { standard bred and } \\
1 \text { quarter horse) }\end{array}$ \\
\hline Sample size: & $n=154$ \\
\hline Intervention details: & $\begin{array}{l}\text { Mares were client owned and divided into groups based on } \\
\text { endometrial swab and culture results obtained pre-breeding. } \\
\text { Group } 1 \text { ( } n=44) \text { : repeat breeders that had clinical findings suggestive } \\
\text { of mucus over-secretion with no evidence of bacterial infection from } \\
\text { culture of uterine lavage fluids. Mares were treated with } N \text { - } \\
\text { acetylcysteine (NAC) } 24-36 \text { hours prior to cover followed by oxytocin } \\
\text { ( } 20 \text { iu IM) } 4-8 \text { hours after infusion } \\
\text { Group } 2 \text { ( } n=85 \text { ): control group of reproductively normal mares } \\
\text { presented on their first cycle showing no evidence of infection or } \\
\text { inflammation on swab and cytology and intra-uterine fluid }<5 \mathrm{~mm} \\
\text { Group } 3 \text { ( } n=25) \text { : mares that had previous positive uterine cultures } \\
\text { treated with lavage and antibiotics on previous cycle and no } \\
\text { evidence of mucus over-secretion, intrauterine fluid }>1 \mathrm{~cm} \\
\text { Mares within these groups were additionally treated with } \\
\text { intrauterine antibiotics ( } 1 \mathrm{~g} \text { ceftiofur) dependent on previous history } \\
\text { and farm management preferences. }\end{array}$ \\
\hline Study design: & Descriptive study \\
\hline Outcome studied: & First cycle pregnancy rate between 13 and 15 days \\
\hline $\begin{array}{l}\text { Main findings: } \\
\text { (relevant to PICO question): }\end{array}$ & $\begin{array}{l}\text { - In mares that were suggestive to have mucous over secretion } \\
\text { (group 1) there was no significant difference in first cycle } \\
\text { pregnancy rates between mares receiving antibiotics and NAC and }\end{array}$ \\
\hline
\end{tabular}




\begin{tabular}{|c|c|}
\hline & $\begin{array}{l}\text { those not receiving antibiotics ( } 80 \% \text { and } 71 \% \text { respectively) } \\
\text { - Similarly, in mares that had previously been treated for } \\
\text { endometritis (group 3) there was no significant difference in } \\
\text { pregnancy rates between mares treated with lavage and oxytocin, } \\
\text { and lavage, oxytocin and antibiotics ( } 50 \% \text { and } 62 \% \text { respectively) } \\
\text { - In mares with no history of endometritis (group } 2 \text { ) the pregnancy } \\
\text { rate was higher for mares that were lavaged with LRS and given } \\
\text { oxytocin (89\%) than those additionally treated with antibiotics } \\
(60 \%)\end{array}$ \\
\hline Limitations: & $\begin{array}{l}\text { - The study was aimed at assessing the potential for NAC to be used } \\
\text { to clear mucous and was not comparing antibiotics as post-service } \\
\text { treatment } \\
\text { - The study was not blinded and it is not possible to tell why } \\
\text { antibiotics were used or not used } \\
\text { - Mares that previously swabbed clean may have been better } \\
\text { identified with a low-volume lavage than uterine swab } \\
\text { - No separation of mare age or status } \\
\text { - In group } 2 \text { mares that had no evidence of infection, } 80 \% \text { of those } \\
\text { treated with antibiotics had greater than } 1 \mathrm{~cm} \text { of fluid or marked } \\
\text { oedema } 18-24 \text { hours post-mating. There was only } 18 \% \text { of mares } \\
\text { with greater than }>1 \mathrm{~cm} \text { of fluid in mares treated with LRS and } \\
\text { oxytocin alone }\end{array}$ \\
\hline
\end{tabular}

\begin{tabular}{|c|c|}
\hline \multicolumn{2}{|l|}{ Noseir (2002) } \\
\hline \multicolumn{2}{|l|}{ Poseir (2002) } \\
\hline \multirow[b]{2}{*}{$\begin{array}{r}\text { Sample size: } \\
\text { Intervention details: } \\
\end{array}$} & $n=36$ \\
\hline & $\begin{array}{l}\text { Mares were assigned into } 4 \text { treatment groups post-mating ( } 9 \text { horses } \\
\text { in each) } \\
\text { Group 1: untreated control } \\
\text { Group 2: intrauterine infusion of antibiotics (1200mg procaine } \\
\text { penicillin with } 1500 \mathrm{mg} \text { dihydrostreptomycin, and } 1500 \mathrm{mg} \\
\text { gentamicin made up to } 20 \mathrm{mls} \text { ) } \\
\text { Group 3: single intravenous injection } 4-12 \text { hours post-mating of } \\
\text { oxytocin (20iu) } \\
\text { Group 4: intrauterine infusion of antibiotics and subsequently } \\
\text { injected with oxytocin intravenously } 30 \mathrm{mins} \text { later }\end{array}$ \\
\hline \multirow{3}{*}{$\begin{array}{r}\text { Study design: } \\
\text { Outcome studied: } \\
\text { Main findings: } \\
\text { (relevant to PICO question): }\end{array}$} & Prospective, non-blinded, non-randomised, controlled trial \\
\hline & $\begin{array}{l}\text { Pregnancy rates at } 60 \text { days post mating either by palpation or rectal } \\
\text { ultrasound }\end{array}$ \\
\hline & $\begin{array}{l}\text { There was no significant difference in pregnancy rates between } \\
\text { mares receiving intrauterine antibiotics alone (57.3\%)or oxytocin } \\
\text { administration alone ( } 52.5 \%) \text {. There was, however, a significantly } \\
\text { higher pregnancy rate between mares receiving antibiotics } \\
\text { combined with oxytocin ( } 67.8 \%) \text { compared to other treatment } \\
\text { groups. There was a significantly higher pregnancy rate in all } \\
\text { treatment groups compared to the control ( } 22.5 \%) \text {. }\end{array}$ \\
\hline
\end{tabular}




\begin{tabular}{|c|l|}
\hline Limitations: & - Small sample size and low power \\
& - No definition given of recurrent and persistent endometritis \\
& - No evaluation of contributing factors such as mare status barren or \\
& rested \\
& - No available data on changes to early embryonic loss with late \\
& pregnancy diagnosis \\
& - A higher proportion of mares that received no treatment had \\
& between 6mm and20mm of fluid (7 mares) compared to mares \\
& that were treated with antibiotics and oxytocin (3 mares) \\
& - No evidence of assessment of underlying bacterial endometritis \\
& from swab or culture results prior to cover \\
\hline
\end{tabular}

\begin{tabular}{|c|c|}
\hline \multicolumn{2}{|l|}{ El-Roos (2003) } \\
\hline Population: & Native bred mares both barren and lactating \\
\hline Sample size: & $\mathrm{n}=115$ (60 barren and 55 lactating) \\
\hline Intervention details: & $\begin{array}{l}\text { Post-breeding mares were randomly assigned into } 9 \text { treatment } \\
\text { groups. } \\
\text { Group 1: no treatment (control) ( } n=13,7 \text { barren, } 6 \text { lactating) } \\
\text { Group 2: intrauterine infusion of } 120 \mathrm{mls} \text { of homologues plasma } \\
\text { ( } n=15,7 \text { barren, } 8 \text { lactating) } \\
\text { Group 3: intrauterine infusion of leukocyte enriched plasma } \\
\text { ( } n=14,7 \text { barren, } 7 \text { lactating) } \\
\text { Group 4: intrauterine infusion of antibiotics ( } 5 \times 10^{6} \text { IU procaine } \\
\text { penicillin and } 2 \mathrm{~g} \text { streptomycin sulphate) ( } n=11,6 \text { barren, } 5 \text { lactating) } \\
\text { Group 5: intrauterine infusion of plasma and antibiotics ( } n=12,6 \\
\text { barren, } 6 \text { lactating) } \\
\text { Group 6: intrauterine infusion of antibiotics and leukocyte enriched } \\
\text { homologous plasma ( } n=13,7 \text { barren, } 6 \text { lactating) } \\
\text { Group 7: intravenous injection with oxytocin at } 0,12 \text {, and } 16 \text { hours } \\
\text { post breeding ( } n=11,6 \text { barren, } 5 \text { lactating) } \\
\text { Group 8: intrauterine infusion with homologous plasma and } \\
\text { intravenous oxytocin given at breeding. ( } n=12,6 \text { barren, } 6 \text { lactating) } \\
\text { Group 9: intrauterine infusion of leukocyte enriched homologous } \\
\text { plasma and intravenous oxytocin given at breeding ( } n=14,8 \text { barren, } \\
6 \text { lactating). } \\
\text { Breeding and treatment was repeated every } 48 \text { hours until ovulation } \\
\text { was detected }\end{array}$ \\
\hline Study design: & Prospective, non-blinded, randomised controlled trial \\
\hline Outcome studied: & Pregnancy confirmed by ultrasound at 45 days \\
\hline $\begin{array}{l}\text { Main findings: } \\
\text { (relevant to PICO question): }\end{array}$ & $\begin{array}{l}\text { Higher pregnancy rates were achieved with the combination of } \\
\text { leukocyte enriched plasma and oxytocin ( } 72 \%) \text {, compared to } \\
\text { leukocyte enriched plasma and antibiotics }(61 \%)\end{array}$ \\
\hline Limitations: & $\begin{array}{l}\text { - Unknown randomisation method, low statistical power, and lack } \\
\text { of statistical tests performed } \\
\text { - Mares received double guarded swabs for culture prior to cover; } \\
\text { however a mare with a positive culture (current endometritis) was } \\
\text { not excluded from the trial. The distribution of mares with }\end{array}$ \\
\hline
\end{tabular}




\begin{tabular}{|l|l|}
\hline & endometritis prior to cover was unknown between the groups \\
& - Unknown presence of clinical or subclinical signs of endometritis \\
& between groups \\
& - Unknown age distribution of mares and inclusion of maiden, \\
& barren and foal heat mares \\
\hline
\end{tabular}

\begin{tabular}{|c|c|}
\hline \multicolumn{2}{|l|}{ Sharma (2011) } \\
\hline Population: & $\begin{array}{l}\text { Thoroughbred mares in India aged from } 3 \text { years to greater than } 18 \\
\text { years }\end{array}$ \\
\hline Sample size: & $N=253$ mares, ( $n=1976$ oestrous cycles) \\
\hline Intervention details: & $\begin{array}{l}\text { Untreated oestrous cycles }(n=1619) \text { (control) with treated oestrous } \\
\text { cycles }(n=357) \text { receiving either: } \\
\text { - intrauterine antibiotics }(n=57) \\
\text { - uterine lavage }(n=30) \\
\text { - oxytocin }(n=55) \\
\text { - intrauterine antibiotics with oxytocin }(n=90) \\
\text { - uterine lavage plus oxytocin }(n=50) \\
\text { - intrauterine lavage plus antibiotics }(n=39) \\
\text { - intrauterine lavage, intrauterine antibiotics, and oxytocin }(n=36)\end{array}$ \\
\hline Study design: & Descriptive study \\
\hline Outcome studied: & Day 16 and day 39 pregnancy rates \\
\hline $\begin{array}{l}\text { Main findings: } \\
\text { (relevant to PICO question): }\end{array}$ & $\begin{array}{l}\text { Significantly higher }(p<0.05) \text { day } 39 \text { pregnancy rates and foaling } \\
\text { rates observed in untreated oestrous cycles }(46.39 \%) \text { than treated } \\
\text { cycles }(40.62 \%) \text {. No difference in pregnancy rates between treated } \\
\text { oestrous cycle and untreated oestrous cycle at day } 16 \text { of pregnancy } \\
\text { ( } 46 \% \text { and } 51 \% \text { respectively) } \\
\text { The incidence of uterine therapies increased with increasing age }\end{array}$ \\
\hline Limitations: & $\begin{array}{l}\text { - There were no criteria defined to determine which treatment } \\
\text { option was chosen and the duration of treatment } \\
\text { - Antibiotic choice and method of administration not discussed } \\
\text { - Unclear at what time antibiotics were used post ovulation and if } \\
\text { other methods were used prior to cover } \\
\text { - No prior history of mares to determine spread of barren, maiden } \\
\text { or foaling mares and if endometritis was present prior to cover }\end{array}$ \\
\hline
\end{tabular}

\section{Appraisal, application and reflection}

Post-service endometritis is a common condition and can be challenging for the clinician to diagnose and treat. Current treatment options for endometritis include intrauterine antibiotics, lavages (LRS or antibiotic infused), other uterine infusions such as mucolytics (NAC, EDTA), immune modulation treatments (plasma), and ecbolic agents (oxytocin and / or prostaglandin). The purpose of this Knowledge Summary was to evaluate the evidence comparing the use of intrauterine antibiotics in the treatment of endometritis to other routine therapies.

The diagnosis of post-service endometritis can be challenging for the clinician and varied between the studies. 4/7 studies compared treatments in mares affected by endometritis whilst the remaining studies 
compared treatment in all mares. Two studies gave descriptions of how they diagnosed endometritis. Sharma et.al., (2011) and Noseir (2002) treated mares with endometritis with no definition stated. Taha (2007) defined persistent mating induced endometritis as a history of repeat breeding of more than 3 natural services without a pregnancy, intrauterine fluid one to two days after breeding, or endometrial cytology showing $>5 \%$ PMN's. Gores-Lindholm et.al., (2013) diagnosed endometritis based on previous cycle uterine lavage fluid with a positive culture, repeat breeding of at least 2 cycles or 2 unsuccessful embryo transfer attempts. The lack of a consistent definition of endometritis makes comparison of treatment options challenging.

The use of controls that did not receive antibiotics was highly variable amongst the studies. The most consistent comparisons used between the studies were either no treatment or ecbolic agents alone. 6/7 studies compared no treatment as a control (Pycock and Newcombe 1996; Pascoe 1990; Taha 2007; GoresLindholm et.al. 2013; Noseir 2002; Sharma et.al 2011), while 4/7 studies compared oxytocin at intervals ranging from 1-72 hours post mating [(Pycock and Newcombe 1996) 72 hours post mating, (Noseir 2002) 412 hours post mating, (El-Roos 2004) 1, 12, 16 hours post mating, (Sharma et.al. 2011) unspecified time/s]. Taya (2007) was the only study to evaluate the use of prostaglandin as an ecbolic agent. Consistently it was observed that treatment of mares with endometritis improved pregnancy rates over no treatment at all (Pycock and Newcombe 1996; Pascoe 1990; Taha 2007; Gores-Lindholm et.al. 2013; Noseir 2002; Sharma et.al 2011). Ecbolic agents and antibiotics had similar improvement to pregnancy rates when used alone (Pycocok and Newcombe 1996; Noseir 2002). The combined effect of antibiotics and ecbolic agents were seen to act in synergy and further improve pregnancy rates (Pycock and Newcombe 1996; Taya 2007; Noseir 2002).

Intrauterine antibiotics have been postulated to not only aid in the treatment of potential pathogens but also by cervical dilation enhancing fluid removal (Pycock and Newcombe 1996). The combination of oxytocin to stimulate uterine evacuation and manual dilation of the cervix has been similarly treated with the use of plasma and uterine lavages (Sharma et.al. 2011; Gores-Lindholm 2013; El-Roos 2004). Gores-Lindholm (2013) demonstrated no significant difference in pregnancy rates for mares previously treated for endometritis with lavage and oxytocin (50\%) compared to lavage, oxytocin and antibiotics (62\%). Similarly, Sharma et.al (2011) showed no difference in day 16 pregnancy rates in mares treated with uterine lavage and oxytocin (52\%) and intra-uterine antibiotics and oxytocin (45\%). While the type, volume of antibiotic and method of antibiotic installation varied between the studies, all involved uterine placement which would have led to cervical dilation.

Supporting the use of antibiotics are culture and sensitivity studies. Common bacterial isolates in endometritis include beta-haemolytic streptococcus, corynebacterium spp, and Escherichia coli (Assad et.al 2015). In all studies, the choice of antibiotic was empirical and not determined by culture and sensitivity results. Four of the studies used a combination of procaine penicillin with streptomycin, gentamicin, framomycin, and or neomycin (Pycock and Newcombe 1996; Pascoe 1990; Taha 2007; Noseir 2002) whilst one study used ceftiofur alone (Gores-Lindholm 2013). Two studies did not comment on the antibiotic used (Sharma et.al., 2011 ; El-Roos 2004), and no studies commented on the use of systemic antibiotics. Whilst the types of bacteria isolated are likely to vary geographically, Assad et.al., (2015) showed all isolates were sensitive to gentamicin and ceftriazone (100\%) followed by tetracycline and chloramphenicol $(92.8 \%)$. There was widespread resistance against streptomycin $(92.8 \%)$ and penicillin $(50 \%)$ which were commonly used in the studies. Sensitivity patterns varied based on which bacteria were isolated, with streptococcus spp having maximum sensitivity to gentamycin and tetracycline antibiotics (100\%) and moderate sensitivity to penicillin (71.4\%), while E. coli isolates were $100 \%$ resistant to ampicillin and streptomycin. Indiscriminate use of antibiotics has shown to increase the risk of fungal and resistant bacterial species (Assad et.al. 2015). Further use of diagnostics to identify the bacterial isolate(s) involved, and antibiotic sensitivity, may aid in the reduction of restricted antibiotics such as tetracyclines and chloramphenicol.

The outcome achieved varied between the studies, with different days of gestation considered. Majority of 
the studies examined for pregnancy at 13-16 days (Sharma et. al 2011; Gores-Lindholm et.al 2013; Pycock and Newcombe 1996), whilst two studies examined only later at 45 days (El-Roos 2004), and 60 days (Taha 2007). 2/7 studies (Pycock and Newcombe 1996; Sharma et. al. 2011) commented on embryonic loss with uterine treatments by comparing pregnancy rates at 12-16 days to 28 days. There was no significant difference in embryonic loss in either study, however Pycock and Newcombe (1996) noted a higher embryonic loss when antibiotics were installed via a syringe compared to a catheter system. Early embryonic loss is estimated to be between $2.6 \%$ to $24 \%$ due to progesterone deficiency or failure of maternal recognition (Vanderwall 2008). Such that the later scanning dates in the studies by El-Roos (2004) and Taya (2007) may have had a higher negative pregnancy rate from early embryonic loss rather than failure to conceive.

Post-service endometritis is a multifactorial disease and can be challenging to manage. Currently the collective data supports the combined use of intrauterine treatments and ecbolic agents to increase pregnancy rates in mares with a history and or signs of endometritis. It is unclear if similar pregnancy results may be obtained with cervical dilation methods that do not include antibiotics in combination with ecbolic agents alone. Further, this summary identifies the need for ongoing research into defining which mares have endometritis in order to determine those that may benefit from treatment. Additional diagnostics such as culture and cytology of endometrial samples post-service could be utilised by clinicians to justify antibiotic usage. Currently clinicians should use intrauterine antibiotics judiciously as they are unlikely to improve pregnancy rates and may be detrimental to fertility in mares with no history or signs of endometritis.

\section{Glossary}

EDTA - Ethylenediaminetetraacetic acid

LRS - Lactate Ringer's solution

NAC - N-acetylcysteine

PMN - Polymorphonuclear Cell 


\begin{tabular}{|c|c|c|}
\hline \multicolumn{3}{|l|}{ Search Strategy } \\
\hline $\begin{array}{l}\text { Databases searched and dates } \\
\text { covered: }\end{array}$ & $\begin{array}{l}\text { Searc } \\
\text { websi } \\
\text { platfo }\end{array}$ & $\begin{array}{l}\text { terms were applied in PubMed Central accessed on NCBI } \\
\text { e (1910-2017), CAB abstracts database accessed on OVID } \\
\text { (1973-2017) }\end{array}$ \\
\hline Search terms: & $\begin{array}{l}1 \\
2 \\
3 \\
4 \\
5\end{array}$ & 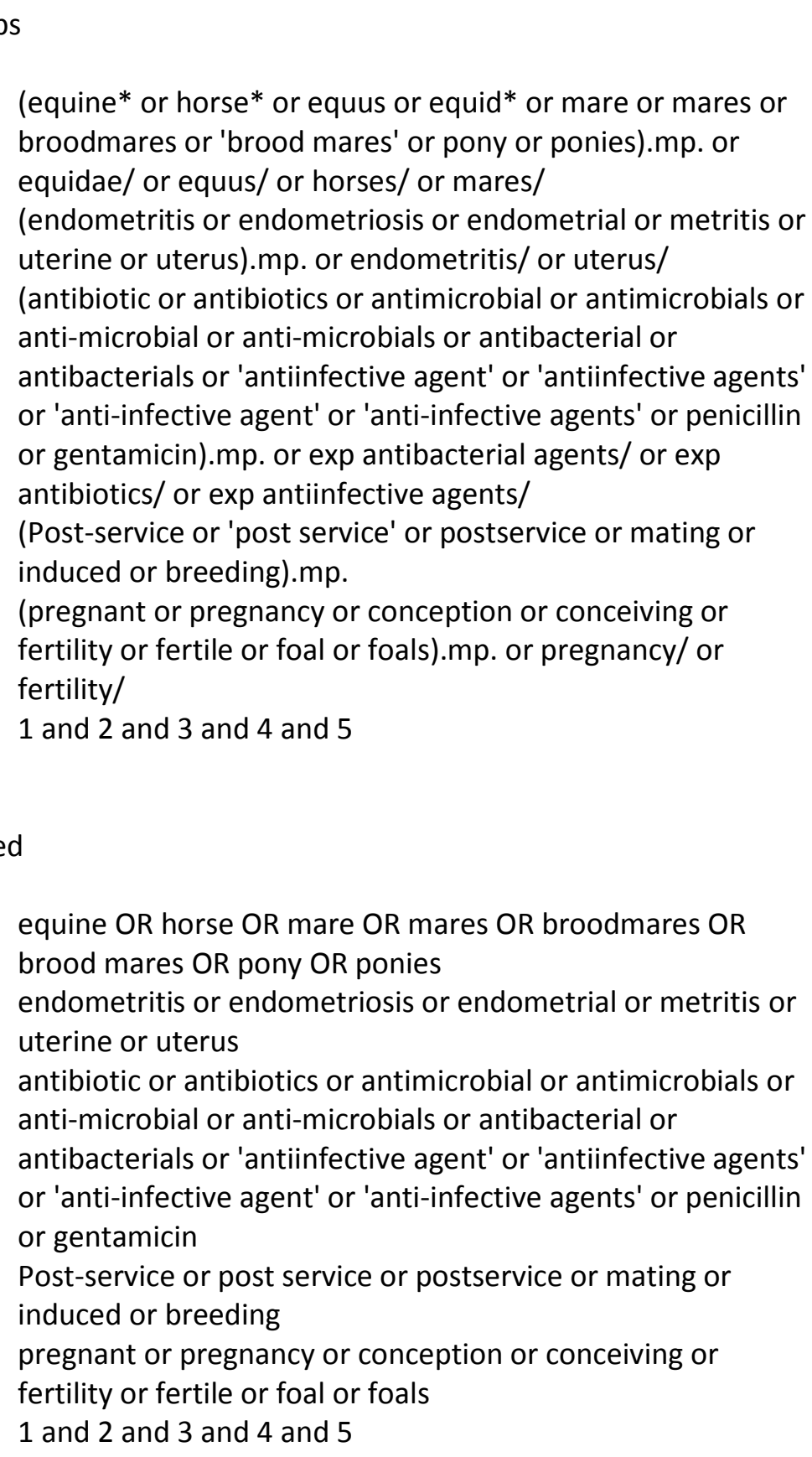 \\
\hline Dates searches performed: & \multicolumn{2}{|c|}{ March 2017} \\
\hline
\end{tabular}




\begin{tabular}{|c|l|} 
Exclusion / Inclusion Criteria & \\
\hline Exclusion: & $\begin{array}{l}\text { Non-English language, narrative or non-systematic review articles, } \\
\text { unpublished data, pharmacokinetic, in vitro or in vivo experimental } \\
\text { studies, artificial insemination protocols. }\end{array}$ \\
\hline Inclusion: & $\begin{array}{l}\text { Any reported use of antibiotics used in post-service treatment from } \\
\text { natural coverings. }\end{array}$ \\
\hline
\end{tabular}

\begin{tabular}{|c|c|c|c|c|c|c|c|}
\hline \multicolumn{8}{|c|}{ Search Outcome } \\
\hline Database & $\begin{array}{l}\text { Number } \\
\text { of results }\end{array}$ & $\begin{array}{l}\text { Excluded - } \\
\text { non-English } \\
\text { language } \\
\text { publication }\end{array}$ & $\begin{array}{l}\text { Excluded - non- } \\
\text { systematic } \\
\text { review article, } \\
\text { conference } \\
\text { proceeding or } \\
\text { letter }\end{array}$ & $\begin{array}{l}\text { Excluded- } \\
\text { artificial } \\
\text { chilled or } \\
\text { frozen } \\
\text { insemination }\end{array}$ & $\begin{array}{l}\text { Excluded - } \\
\text { pre-service } \\
\text { treatment } \\
\text { not post } \\
\text { service }\end{array}$ & $\begin{array}{c}\text { Excluded - } \\
\text { did not } \\
\text { answer PICO } \\
\text { question }\end{array}$ & $\begin{array}{l}\text { Total } \\
\text { relevant } \\
\text { papers }\end{array}$ \\
\hline $\begin{array}{l}\mathrm{CAB} \\
\text { Abstracts }\end{array}$ & 53 & 3 & 15 & 6 & 2 & 20 & 7 \\
\hline $\begin{array}{l}\text { NCBI } \\
\text { PubMed }\end{array}$ & 25 & 1 & 5 & 2 & 0 & 15 & 2 \\
\hline \multicolumn{6}{|c|}{ Total relevant papers when duplicates removed } & & 7 \\
\hline
\end{tabular}

\section{CONFLICT OF INTEREST}

The authors declare no conflicts of interest.

\section{REFERENCES}

1. Ahmad, M., Ahmad, N., Mansoor, M.K. and Samad, H.A., (2001) Synergistic effect of antibiotics and oxytocin in the treatment of endometritis in mares. Pakistan Veterinary Journal, 21 (4), pp. 202-205

2. Assad, N.I., Bugalla, N.S., Chandolla, R.K. and Sharma, A., (2015) Isolation and Antibiotic Sensitivity of Uterine Microbial Pathogens- A study of 30 Endometritis Affected Mares. Intas Pollivet, 16 (2), pp. 223230

3. Blanchard T.L., Varner, D.D., Schumacher J. Love C.C., Brinkso, S. and Rigby S 2003, Manual of Equine Reproduction ed. Mosby, Philadelphia, USA

4. El-Roos, M.E.A.A., (2004) Some Post-Breeding Treatments for improving fertility in mares. Veterinary medical journal Giza. 52, pp. 89-98 
5. Gores-Lindholm, A.R., LeBlanc, M.M., Causey, R., Hitchborn, A., Fayrer-Hosken, R.A., Kruger, M., Vandenplas, M.L., Flores, P. and Ahlschwede, S., (2013) Relationships between intrauterine infusion of $\mathrm{N}$-acetylcysteine, equine endometrial pathology, neutrophil function, post-breeding therapy and reproductive performance. Theriogenology. 80, pp. 218-227.

DOI: https://doi.org/10.1016/i.theriogenology.2013.03.026

6. LeBlanc, M.M. and Causey, R.C., (2009) Clinical and Subclinical Endometritis in the Mare: Both Threats to Fertility. Reproduction in Domestic Animals. 44 (3), pp. 10-22.

DOI: http://dx.doi.org/10.1111/j.1439-0531.2009.01485.x

7. Morel M.C.G.D 2003. Equine Reproductive Physiology, Breeding and Stud Management 2 ed. Wallingford, United Kingdom: CABi

8. Noseir, W.M.B., (2002) Effect of Clearance of uterine fluid on pregnancy rate in mares susceptible to endometritis. Veterinary medical journal Giza. 50 (2), pp. 281-287

9. Pascoe, D.R., 1990, Effect of Post breeding infusions on conception rates and foaling rates, Proceedings of the twelfth Bain-Fallon Memorial lectures, Equestrian Veterinarians Australia, Townsville, QLD, pp. 187-192.

10. Pycock, J.F. and Newcombe, J.R., (1996) Assessment of the effect of three treatments to remove intrauterine fluid on pregnancy rate in the mare. The Veterinary Record. 138, pp. 320-323. DOI: http://dx.doi.org/10.1136/vr.138.14.320

11. Ricketts, S.W., (1997) Treatment of equine endometritis with intrauterine irrigations of ceftiofur sodium: a comparison with mares treated in a similar manner with a mixture of sodium benzylpenicillin, neomycin sulphate, polymyxin B sulphate and furaltadone hydrochloride. Pferdeheilkunde, 13 (5). Pp. 486-489. DOI: http://dx.doi.org/10.21836/PEM19970510

12. Sharma, S., Dhaliwal, G.S., Gosal, N.S. and Varun., (2011) The impact of uterine therapies on reproductive efficiency in Thoroughbred mares; the possible effect of mare age and reproductive status. Veterinarski Archiv, 81 (2), pp/ 163-173

13. Taha, M.B., (2007) Treatment of persistent mating induced endometritis in Arabian maiden mares. Journal of Animal and Veterinary Advances. 6 (5), pp. 718-722

14. Vanderwall, D.K., (2008) Early Embryonic Loss in the Mare. Journal of Equine Veterinary Science, 28 (11). Pp. 691-702. DOI: http://dx.doi.org/10.1016/j.jevs.2008.10.001 


\section{Cinam \\ ochese}

\section{Intellectual Property Rights}

Authors of Knowledge Summaries submitted to RCVS Knowledge for publication will retain copyright in their work, and will be required to grant to RCVS Knowledge a non-exclusive license of the rights of copyright in the materials including but not limited to the right to publish, re-publish, transmit, sell, distribute and otherwise use the materials in all languages and all media throughout the world, and to license or permit others to do so.

\section{Disclaimer}

Knowledge Summaries are a peer-reviewed article type which aims to answer a clinical question based on the best available current evidence. It does not override the responsibility

of the practitioner. Informed decisions should be made by considering such factors as individual clinical expertise and judgement along with patient's circumstances and owners' values. Knowledge Summaries are a resource to help inform and any opinions expressed within the Knowledge Summaries are the author's own and do not necessarily reflect the view of the RCVS Knowledge.

Veterinary Evidence and EBVM Network are RCVS Knowledge initiatives. For more information please contact us at editor@veterinaryevidence.org

RCVS Knowledge is the independent charity associated with the Royal College of Veterinary Surgeons (RCVS). Our ambition is to become a global intermediary for evidence based veterinary knowledge by providing access to information

that is of immediate value to practicing veterinary professionals and directly contributes to evidence based clinical decision-making.

www.veterinaryevidence.org

RCVS Knowledge is a registered Charity No. 230886. Registered as a Company limited by guarantee in England and Wales No. 598443.

Registered Office:

Belgravia House

62-64 Horseferry Road

London SW1P 2AF 